\title{
Methods of Grammar Teaching at College
}

\author{
Liwei Sun \\ School of Arts and Science, Jilin Agricultural Science and Technology College, Jilin 132101
}

Keywords: Grammar Teaching, Methods, College.

\begin{abstract}
This paper explores with the condition of college English grammar teaching, including three traditional methods of grammar teaching and communicative language teaching, then compares them, and digs out the differences between them. The nature of grammar determines the significance of grammar teaching. The significance of grammar teaching determines the importance of choosing rational methods of grammar teaching. This paper shows five methods of grammar teaching which play an important role in improving college grammar teaching.
\end{abstract}

\section{Introduction}

Grammar, as a somewhat ambiguous term today has been defined in different ways by different linguists. Stern defines grammar as "that branch of the description of languages which accounts for the way in which words combines to form sentences”(Stern, 1983), Brown thinks grammar as “a system of rules governing the conventional arrangement and relationship of words in a sentence"(Brown, 1994). The most common definition of grammar is that, grammar is a set of rules which tell us how words change their forms and how they are put together to formulate phrases and sentences. A language is made up of phonetics, vocabulary and grammar, without which, there would be no language. However, with the development of communicative approach, people lay emphasis on cultivating students' communicative competence and neglect the importance of grammar teaching at college. It is an erroneous attitude. Marianne Celce-Murcia says "Noticeable and convincing proof shows teaching without grammar can only lead to cripple in foreign language whether it is based on comprehension or on communication. Students can't make progress if surpassing the stage”(Celce-Murcia, 1985:20). Thus, treating grammar teaching rightly plays an important role in improving the level of college English teaching.

\section{Three traditional methods of grammar teaching}

\section{Grammar-translation method}

Howatt asserts that the grammar-translation method began in Prussia at the end of the eighteenth century.(Howatt,1984) It is the most traditional method for language teaching, which has dominated China's language classroom for several decades. The aim of this method is to help learners to access and appreciate great literature and to translate literary works through extensive analysis of grammar of the target language.

In regard to grammar teaching, the characteristics of the grammar-translation method may be summed up as follows: 1)Classes are taught in the mother tongue, with little active use of the target language. 2)Grammar teaching is teacher-centered. The teacher occupies most of the class time and explains grammar rules, while learners hardly have any practice but memorize the grammatical information mechanically. 3) The sentence is the basic unit of teaching and language practice. It is treated out of context without any practical value. 4) Little attention is paid to the context of texts, which are treated as exercises in grammatical analysis. In this method, grammar is viewed as an end and is taught for its own sake. It pays too much attention to grammatical rules, but no attention is given to the practice of using language meaningfully in a real context. In this regard, we are not surprised to see that many students with years of formal English grammar training cannot communicate properly. 


\section{Direct method}

Originating in the nineteenth century, the direct method can be partly attributed to Berlitz, a practical and unconventional teaching reformer. This method stresses the spoken language rather than the written language. Therefore, in the classroom teachers present new language by using mime, pictures, objects, and demonstration in order to avoid the use of learners' native language. Much of the class time is devoted to question and answer exchanges between teachers and students. Grammatical rules are not explicitly taught, but teachers encourage students to induce the rules of grammar. The direct method also has some drawbacks that are as follows: Grammar teaching focuses on grammatical rules and is sentence-oriented. Therefore, grammar cannot be used in real communication. This method neglects to foster learners' writing and reading skills.

\section{Audio-lingual method}

The audio-lingual method is based on both the structural linguistics and the behavioral psychology of the 1950s.In terms of structural linguistics, spoken language should be learned before written language, as it is argued that language is "primarily what is spoken and only secondarily what is written".(Brooks, 1964) And in the light of behavioral psychology, language learning is considered as a mechanistic process of habit formation: stimulus-response-reinforcement. The following is a summary of the main features of the audio-lingual method: 1) Correct pronunciation, intonation, and error free utterances are reinforced. 2) This method focuses on listening and speaking rather than reading and writing. 3) Structural patterns are never explained grammatically. 4) There is overuse of repetition and memorization of pattern drills. 5) Language performance consists of a set of habits; therefore, students do not have to understand the grammar in order to use it. In this method, there is little or no grammatical explanation because the advocates hold the view that knowledge of grammatical rules would only obstruct the mechanical formation of habits. Grammar is learned through mimicry, repetition and rote memorization exercises.

\section{The methods to improve grammar teaching}

\section{Grammar teaching in the communicative way}

Generally speaking, grammar teaching in the communicative way can be divided into the following stages:1) presenting grammatical points by using situations. 2) teacher-student discussion. 3) summing up. 4) consolidation practice. 5) comprehension. All these stages will be discussed in detail.

Creating situations by using pictures in the texts or acting is one of the most commonly used methods in grammar teaching. The teacher may make full use of texts or the pictures in the text books to make the students interested in the grammatical point they are going to learn. The second way is the teacher and the students may carry out communicative dialogue to create different situation. The last way is to create situations by telling stories or narrating events. The teacher may invent a story or narrate an event which contains new grammatical items and tell the students the story in class or ask them to listen to the story over the recorder.

Teacher and students should be clear about the aim of discussion. The students may induce the grammatical rules with the teacher's guidance. The teacher provides relevant patterns to make the students more acquainted with the rule and understand the function and meaning of the language material given. The teacher should try his or her best to get the students more involved in the discussion and work together to discover language rules hidden in the materials.

On the basis of the teacher-student discussion, the teacher summarizes the concerning grammatical item and explains it. Of course, the explanation is different from that in the grammartranslation method and the teacher should pay attention to it.

Mechanical practice: practice the new rule by putting it in certain situation and make it meaningful. At this stage, language accuracy should be stressed. The teacher may give some key words and correct the students' mistakes whenever possible .e.g.: After learning be going to, the teacher says:“I' m going to do some reading at home this Sunday. What are you going to do?” The students are then required to say sonic sentences related to their own life as the teacher does. 
Flexible practice: on the basis of mechanical practice, the students are required to practice a certain grammatical rule flexibly which should be combined with a certain situation and which is less difficult than comprehensive practice. e.g.: The teacher gives the students a topic "How did you spend your last weekend?”The students then say a few sentences concerning what he really did so that the past indefinite tense is practiced.

At this level, a new grammatical rule is not solely practiced. However, it should be integrated with other rules, which have been learned. The focus of this stage demands the comprehensive and efficient use of things, which the students have already learned. The teacher must not correct the mistakes to guarantee the smooth communication and the error correction work can be done when the practice is over. Comprehensive use can be carried out in the followingway:1) The teacher may provide a topic concerning the text for the students. 2) Imagine situations for practice or discussion. 3) Tell stories and conduct dialogues after looking at a series of pictures or watching some video clips.

\section{Inductive sequence to teach grammar}

Educationally speaking, on many occasions, we should use the inductive sequence to teach grammar, that is example---practice---rule "because it encourages language learners to start out from their own observations and to discover the principle or rule for themselves rather than being told in advance what the rule is"[13]. For example, when introducing the word glance, the teacher may first ask the students to tell meaning and usage in the context so that they may obtain some clues from it, and then write down the examples on the blackboard: 1) Father used to take a glance at/over the newspaper headlines at breakfast. 2) The letter was so short that I finished it at a glance. 3) Father glanced over the newspaper headlines at breakfast. 4) She glanced shyly at him from behind the harp. (Quoted in Teacher's Book, Intensive Reading College English 1998,40). From those examples, the teacher may help the students infer the form, the function and the meaning of glance. However, on many other occasions, the teachers cannot expect the students to discover the grammatical rules or principles for themselves, so the deductive sequence cannot be completely ruled out. According to Stern, “In any case, even if discovery learning is the teacher's goal, the examples are often quite justifiably pre-selected, and so the discovery of a grammatical principle is often a carefully guided rediscovery rather than one which is based on natural language behavior" (Stern, 1992)

\section{Making old things new}

Pattern drill is one of the major ways to teach grammar in English classes in China. But in recent years, it has become a target of attack, for the repeated training of a sentence pattern is far beyond real communication. But the teachers can go one step further to make pattern drills communicative. Mechanical drills, meaningful drills, and communicative drills can bring new meaning to the teaching of grammar in our country. In mechanical drills, there is complete control of the response so that the student does not even need to understand the drill and to produce the correct response. It suggests that if a nonsense word can be inserted as effectively by the student as a meaningful word, then the drill is one of the mechanical types. But the students cannot complete the drill without fully understanding structurally and semantically what he is saying.The following is an example of a meaningful drill: Question: When did you arrive this morning? Answer: I arrived at nine o'clock. Question: When will you leave this morning? Answer: I'll leave at six o'clock. In communicative drill, however, there is no control of the response, the student has free choice of an answer, and the criterion of selection here is his own opinion of the real world-whatever he wants to say. e.g. Question: What did you have for breakfast? Answer: I had toast and coffee for breakfast. Or: I over slept and skipped breakfast, so I wouldn't miss the bus.

\section{Teaching grammar in the context}

Under the communicative background, the teachers should be clear that, in the course of grammar teaching, it is all right to focus on communication. In fact, when we teach some grammatical points, sometimes it is very hard to use communicative approach. For example, it is difficult to teach the subjunctive mood in the communicative way, because it is seldom used in daily communication. Not being able to use the communicative way does not necessarily mean that 
we should invent many isolated sentences which can never be used in daily communication in order to demonstrate a certain grammatical point. Grammatical pointscan be put in a context, have the students feel it, and give them appropriate instructions. Take a look at the following passage:

When you travel abroad you will see, in many countries, behavior that demonstrates the influence of other value systems. You will observe people elbowing their way to a ticket window instead of waiting their turn in a line. You will see motorists totally oblivious of the rights of pedestrians. You will see people behave inconsiderately toward those who have less power than they while fawning on those with more power.

The fact that you would notice this behavior and that you would be disturbed, it demonstrates you own acceptance of the Judeo-Christianethic, because each of the examples above clearly violates it. If, on the other hand, you were a native to the foreign culture, you would be taught to hold the values of that value-you would struggle toward the ticket window an regard anyone as "peculiar" if he looked about for a line to stand in; you would, as a pedestrian, "know" that the motorist had the right of way.

After reading the two paragraphs, the students may feel what the subjunctive mood is really like and how it is used.

\section{Conclusion}

With the urgent requirement of communicative competence in modern society, the social communicative function is overemphasized in language teaching classroom. This paper reviews many stages of teaching methods development and wants to illustrate that although the communicative approach shocks the traditional language teaching which is grammar centered, grammar is also the theoretical basis of foreign language teaching. Therefore, at present, in order to give serve to cultivate the communicative competence in English most efficaciously, English teaching at college should pay enough attention to English grammar, and make great effort to improve the efficiency of grammar teaching. Certainly, grammar teaching is only a means not the end, so we should master the position of grammar teaching in the whole English teaching, and know about its function which should not be exaggerated or be underrated.

\section{References}

[1] Brooks, J. G. Teaching English as a Foreign language .Routledge and Kegan Paul Ltd. England.1964.

[2] Brown, H.D. Teaching by Principles. Prentice Hall. New Jersey.1994.

[3] Celce-Murcia, Making informed decisions about the role of grammar in language teaching. TESOL, NEWSLETTER, Vol, XLX M. 1985.No,1:20

[4] Howatt, A. P. R.A History of English Teaching. Oxford University Press. 1984.

[5] Stern. H. H.Functional Concepts of Language Teaching. Oxford University Press. 1983.

[6] Stern. H. H. Issues and Options in Language Teaching. Oxford University Press.1992. 